\title{
Public Housing in Semarang and the Modernization of Kampongs, 1930-196o
}

\author{
Radjimo Sastro Wijono
}

\section{Introduction}

As one of the major colonial urban centres in Java, Semarang was one of the first cities in the Netherlands Indies to gain a measure of municipal autonomy under the Decentralization Act passed in 1903. The newly established municipal council rapidly developed itself into a think-tank, which elaborated a colonial discourse concerning urban health, sanitation, housing, and the indigenous urban inhabitants. The kampong became a prime focus of attention of the municipal administrators (Nas 1998; Coté 2002; Versnel and Colombijn, this volume). Faced with a rapidly expanding urban Javanese community, a tragic recent history of cholera and plague epidemics, and a burgeoning commercial sector, members of the new municipal council of Semarang and its specialist committees urgently began to examine the best ways to set about reforming living conditions. The initiatives the council implemented over the next decade provided important guidelines for the development of public health policy, town planning, and public housing followed by many other cities in Java and other islands in the colony.

The pressing health and sanitation issues and the desperate need for adequate housing inevitably led urban reformers to advocate innovations which implied a multitude of underlying new ideas and practices. In their turn, these had an impact upon the cultural and domestic practices of indigenous urban kampong residents as well as on traditional methods of house construction. No less important in their impact were the specialization of tasks in the building process and the diffusion of new materials and new skills which were increasingly required for the mass housing projects that were being undertaken (Nas and Boender 2002).

Hygiene ranked very high on the list of priorities of urban government officials who were concerned with the effects of regular epidemics of the plague, cholera, and typhoid, which occurred with increasing incidence in the latter years of the nineteenth century (Tillema 1913). When theories about the specific causes of such epidemics became more widely understood in the colony, policies were developed which directly challenged indigenous practices in traditional house construction, in particular the pitched roofs and thatching

(C) RADJIMO SASTRO WIJONO, 2015 | DOI 10.1163/9789004280724_008

This is an open access chapter distributed under the terms of the Creative Commons Attribution-

Noncommercial 3.0 Unported (CC-BY-NC 3.0) License. 
which, it was held, sheltered rats and other vermin. In many cases, such houses were torn down or re-roofed using such new materials as corrugated iron. Moral arguments, articulated by philanthropic and religious interests working in urban Java, and by missionaries in more distant parts of the archipelago, were often linked to more 'scientific' ones. To the anxieties about the insanitariness of traditional housing was added a concern about the domestic arrangements their architecture implied. These, for instance, allowed the cohabitation of several families in one house or several generations of one family in a single space. Intentionally or not, new designs, new materials, and new practices often challenged traditional beliefs and rituals related to family relations, childrearing, or nutrition.

When ideas and regulations concerning better housing ran counter to the existing norms and values of indigenous residents, they can be characterized, in part, as a 'civilization offensive' against Javanese and Chinese domestic traditions and as an attempt to bring habitation styles and domestic life in general into line with European traditions and recent European scientific discoveries. In part, they were also simply the result of a general diffusion of new ideas, techniques, and materials, such as taking account of sanitation, or the use of corrugated iron roofs, and bricks and concrete in construction. These municipal programmes introduced significant changes into the character of public settlement and in this sense a house as a residence became a catalytic element of modernization.

This mission civilisatrice through the medium of housing was an early form of globalization, or more precisely, the implementation of Western conceptualizations of health and hygiene in all the colonies. This process was promulgated more rigorously in some areas than in others, which might be one explanation for the great regional differences in the present-day condition of vernacular architecture in Indonesia. Since the first generation of Indonesian architects and town planners were trained during this energetic period of professional development and experimentation, they largely persisted in following this pattern in the immediate postcolonial period. Consequently, in the process of decolonization, architecture and town planning in Indonesia, as elsewhere in South-East Asia, continued to be largely inspired by such Western models without any significant reference to national (traditional) architecture, except for aspects of surface decoration (Colombijn 2010: 281-97, 336-348; Dumarçay 1987:70-71; Van Roosmalen, this volume). In subsequent years, Indonesian architects and planners turned to the latest overseas - increasingly Asian - models in their efforts to meet the demand of expanding and aspiring urban lower and middle classes, constructing Indonesian versions of gated communities and high-rise apartments. 
The subject of this chapter is how these developments in housing and the concomitant social changes worked out in public housing built by the municipality (gemeente) of Semarang in the last decades of colonial rule. It begins by identifying the main trends in public housing, which appeared especially in two municipal housing complexes in Semarang, Sompok, and Mlaten. This is followed by an analysis of how the new housing introduced the residents to some aspects of modernity. Next the changes which inevitably occurred during the transfer to independence and those which appeared earlier during the Japanese interregnum will be sketched. The chapter will conclude by arguing that modernization, both as a conceptual notion and as physically embedded in the urban landscape, was such a powerful element in the late colonial period that the city experienced very little change in its built form with the end of colonialism. The only real change was a dramatic burst in population growth.

\section{Organizing Public Housing in Semarang}

In the first half of the twentieth century, Semarang was the administrative centre of central Java and it was the commercial hub of the region. It was the centre of a rail and communications networks, infrastructural services for a thriving sugar industry, and a busy seaport (Stevens 1986; Suryo 1982). Between 1905 and 1920, the population, which was ethnically mixed, swelled from 96,000 to 158,000 and by 1930 it had grown to 218,000 . The expansion of the population was primarily attributable to the influx of Javanese from the hinterland, attracted by the work opportunities the city provided. It was also home to a significant Chinese population, whose leading figures dominated the commercial and financial sector and also had control of much of the land. In 1905, 78 per cent of the population was indigenous, fifteen per cent Chinese, five per cent European and two per cent was made up of Arabs and other Asian peoples. In 1930, the indigenous population continued to dominate, but its share had shrunk slightly (Semarang 1919; Volkstelling 1930 1936, VIII:2, 78-81).

The perceived poor condition of the urban kampong of the Javanese and Chinese residents of Semarang at the beginning of the twentieth century encouraged the municipal administration of Semarang, from its inception, to develop programmes of kampong improvement (kampongverbetering) and public housing (Westerveld 1910). Semarang was rich in citizens who contributed to this spate of early urban housing reform in Java in the first half of the twentieth century. It was also the home of the progressive colonial newspaper, De Locomotief, which had been at the forefront of calls for colonial reform in the latter half of the nineteenth century, and of a variety of religious and 
philanthropic organizations. By the end of the second decade of the twentieth century Semarang had become known as the 'red city', a reference to its role as the home of an organized indigenous labour movement which had grown under the influence of a group of radical European self-proclaimed socialists (Shiraishi 1997).

Among the progressive figures in the town was the colonial architect and town planner, Thomas Karsten, who assumes a central place in colonial town planning. Karsten commenced his colonial career in Semarang in 1914 and the influence of his work and writings soon spread throughout the Indies (Sumalyo 1993). Another significant Semarang figure was H.F. Tillema, a pharmacist and businessman. A resident of Semarang, Tillema played a central role in calling for improvement in housing and living conditions for both the European and indigenous inhabitants of Semarang and later in the whole of the Netherlands Indies (Coté 2002). Tillema pointed to the link between technical elements of housing construction and the improvement of health conditions of the indigenous population. Tillema (1922, V:ix) considered the traditional house to be an important breeding ground of illnesses and stressed that it was essential to improve the housing conditions to keep the houses plague free, including to ensure good light and ventilation, and to take care of proper sewage and garbage disposal. On the wider scale, he also stressed the importance of adequate town planning ordinances to regulate the overall arrangement of residential areas.

Semarang was also blessed with a number of well-trained, committed professionals, including doctors, such as Terburgh, municipal town engineers such as Rückert (Versnel and Colombijn, this volume) and Plate, who went on to contribute more broadly to the urban development of Java, and leaders such as the Semarang mayor, De Iongh. In conjunction with the businessman Tillema and the architect Karsten, these men all made their reputations at the beginning of the twentieth century by tackling the problems of the city of Semarang.

These new technocrats helped convince councillors that overcrowding in the densely settled Javanese and Chinese kampongs represented a health hazard to the European community and that these health problems related directly to business confidence and investment in the city. Although the lives of Europeans were directly affected by the health of their Javanese neighbours, it was the latter who were most prone to be the victims of the high incidence of cholera and typhoid and who were most affected by the high child mortality rates. It was they who had to cope with the lack of fresh water, inadequate sanitation, overcrowded dwellings and over-populated kampongs.

By the middle of the second decade of the century, the answer to the problems that beset Java's cities was clear to the city government: they could only 
be solved in the longer term by taking the initiative to build new, healthier housing complexes, and separating these from the industrial and commercial areas of the city. Therefore, the municipality Semarang made public housing a priority and embarked on a programme, which can be seen as one of the success stories in the history of the city. The city administration set to work devising a myriad of rules and regulations to enforce building regulations, impose proper sanitary habits, and maintain traffic flows and orderly environments. Indeed, it did not try to avoid grappling with the entire issue of settling large numbers of poor people in an orderly and regulated way. Through the work of highly qualified bureaucrats and technocrats, and pushed through by the progressive principles of its municipal leaders (including Javanese and Chinese representatives), the municipality developed seven public housing complexes. One of these, Complex Sompok, will be examined in more detail here.

After some years of debate, the Semarang municipality commenced its first large public housing project 1916. Its aim was to supply the needs of its citizens by producing large numbers of low cost houses by resorting to mass production on a commercial basis. This would have the added advantage that it would generate income for the city. It contracted Thomas Karsten, who had arrived in Semarang in 1914, as the city planner to develop this project. Karsten was concerned about producing buildings and urban environments which would attempt to integrate European and indigenous elements and is widely credited with having succeeded in doing so. His ideas about architecture and town planning, in particular the arrangement and integration of the city into different zones, ensured that his name assumes a central place in the history of colonial and Indonesian architecture (Sumalyo 1993).

The Complex Sompok was developed in two stages: in 1919 Karsten finished the design and between 1920 and 1923 the local government completed the construction of the housing complex (Liem 1931:261). By the end of 1918, an area of 9,90o sq $\mathrm{m}$ suitable for the construction of thirty-three units had been surveyed, plus another $5,785 \mathrm{sq} \mathrm{m}$ to accommodate four houses designated as so-called European houses. At the end of 1919, the Council had prepared another 28,000 sq $\mathrm{m}$ for 156 kampong dwellings, and 12,078 sq $\mathrm{m}$ for another eight European residences (Gemeente Semarang 1918).

Conspicuous in this early experimental period of public housing were the more progressive attempts to combine elements of traditional indigenous architecture with the principles of modern Western health, hygiene, and construction. Remarkably, these modern, Western ideas were only just then being developed and applied in urban housing projects in Europe. The idea of incorporating traditional elements in modern architecture had already been tried by a number of Western architects working for colonial administrations in 
South-East Asia, but had only rarely succeeded. The names of G. Grolier, working in Phnom Penh and Maclaine Pont in Java are amongst those colonial experimenters who did succeed to some extent in achieving this aim. But in Indonesia it is Thomas Karsten who is credited with having been most successful in integrating European and indigenous elements in houses designed for a modern indigenous urban population.

In developing his kampong house design, Karsten paid due respect to Javanese domestic tradition and simultaneously accommodated the latest technical innovations related to modern concepts of health and sanitation. Despite needing to develop affordable mass housing, he also emphasized the necessity of ensuring diversity in the style and structure of the houses. To ensure a variety in housing style in this huge complex, Karsten devised a number of house 'types', built to size and cost specifications suited to what he perceived to be the needs of families of different socio-economic levels. Of the eighty-one new houses which had been built by 1919, twenty-one houses were of Type II, forty of type IV and twenty of Type V (Figure 7.1). Type II houses were provided with a simple bathroom, washroom and privy. Type $\mathrm{V}$ houses had an additional space which consisted of kitchen, with adjacent bathroom and privy. This additional space was connected to each group of four houses in

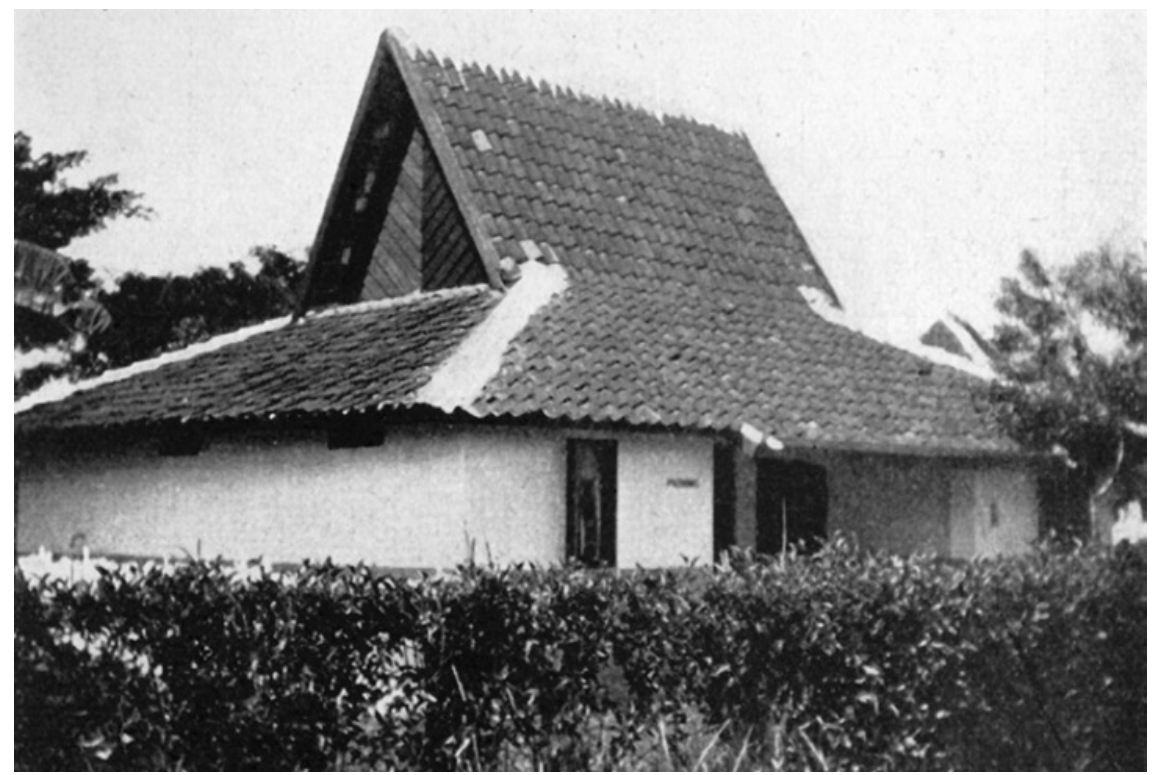

FIGURE 7.1 House type Vin Sompok SOURCE: FLIERINGA (1930:183) 
such a way that one septic tank served every eight houses (in two clusters of four). Some of the more expensive designs included a gravel-based septic tank. Each house had a brick wall $0.8 \mathrm{~m}$ high and $0.3 \mathrm{~m}$. wide separating it from the next, avoiding the use of traditional bamboo plaited walls which were brittle and decayed too rapidly. These houses were rented out by the Gemeentelijk Woningbedrijf (Municipal Housing Corporation) for rents varying according to the different size houses: Type II cost 494 guilders, Type IV, 703 guilders, and Type V 773 guilders per year (Gemeente Semarang 1919). The most expensive type had the added $4 \times 4 \mathrm{~m}$ space and shared use of a gravel-based septic tank.

The council supervised these pioneering developments closely and intervened in Karsten's initial plans when it felt that the houses were too close together. In 1918, it removed one house from every group of four in Karsten's initial design. At the end of the same year, the council also decided to provide the cheaper houses with detached kitchens. These were to be constructed from bamboo to cut the extra costs. By the end of 1919, detached kitchens made of bamboo were common (Gemeente Semarang 1919).

The municipal government benefited in its building activity from the stable economic conditions at the time and the good income it received from taxes. Therefore, the years 1916-1922 formed a period of initiative and development. In one year alone, the municipal council built 519 houses in Sompok at a total cost of 480,000 guilders. So successful was the public housing project that very quickly it used up all the available land, including that of the existing kampongs of Kintelan and Lempongsari. While the new project housing did not destroy the old kampongs, new municipal houses were built in the interstices between the old houses, producing strange juxtapositions. For instance, the old housing of kampong Lamper Lor remained in the midst of new housing of kampong Jeruk and Rambutan.

The insertion of new kampong housing into the area of old kampongs introduced new divisions in terms of the built environment and in terms of the nature of the population. The complex Sompok, also known as Kampong Gemeente, for instance, was devoted to housing lower-ranking civil servants. Sompok was also distinguished from the older kampongs onto which it abutted by its layout with regularly placed parks (plantsoenen). The green image of Kampong Sompok was strengthened by the decorative neighbourhood names, taken from fruit trees, such Kampong Manggis, Jeruk, and Rambutan (Gedenkboek 1931).

By the end of 1929, the Municipal Housing Corporation of Semarang had built 1782 houses (Rückert 1930:167-170). This was a relatively small number given the population growth over that time and municipal housing provided for only a small proportion of the housing needs of the total population. 
Despite this criticism, Semarang had made a greater effort than any other city in the Netherlands Indies in providing public housing (Colombijn 2011). Besides Sompok, public housing in Semarang also included the housing development in Candi Baru, Kintelan, and East Semarang. After 1916, a separate technical department was created to oversee this development and the housing department became an institution, which assumed a range of social functions related to public housing. Its duties included surveying and constructing roads, implementing policies related to health and sanitation for housing and its environment, and designing and implementing infrastructure for traffic, industry, trade, and other facilities. Generally speaking, its tasks were aimed to meet the demands of designing a better life in the present and future.

In 1924 responsibility for housing development was taken over by a limited liability company, NV Volkshuisvesting. The central government furnished 75 per cent of the capital and the municipality 25 per cent. Similar companies were founded in other large cities of the colony (Flieringa 1930:140-143, 150153; Rückert 1930:169). The bulk of the houses of the NV Volkshuisvesting were rented, at costs of between three and 35 guilders per month and some houses were sold. This housing company operated smoothly and successfully until 1930 with a capital in 1929 of 1.4 million guilders. In that year, just before the onset of the Depression, the company was able to sell around 580 houses, eighteen stores and six shops (Rückert 1930:163-169).

However, during the Depression, NV Volkshuisvesting suffered a severe setback. Many occupants moved out of these houses to other dwellings with lower rents or moved back to the village. After Independence, responsibility for new and existing public housing and the exploitation of urban land for housing was taken over by the Dinas Djawatan Gedung-Gedung Kota Besar Semarang (Semarang Municipal Department of Buildings). In 1950, it allocated a significant number of houses to veterans of the War of Independence.

\section{Some Problems in Public Housing}

Two key issues remained a problem throughout the twentieth century. The first was funding for public housing. Municipal autonomy also meant financial autonomy and, although the central government did provide some financial support, one of the motivations behind decentralization had been to encourage local government to develop its own sources of funding through differing forms of taxation. Initially the central government was not prepared to support the provision of urban public housing financially. When it changed 
its policy later, the amount was never sufficient to cover all the needs of Semarang. From time to time, municipal councils sold public land to private developers to raise money to add to that received from the government in the form of loans and during the colonial period, the local government of Semarang was able to service its debts. After independence the municipality continued building housing complexes to meet public housing needs, especially those of its own civil servants. Limited financial resources forced public housing authorities to co-operate with private companies and to run lotteries as a means of raising funds. The political instability, which persisted for much of the early period of the Republic, added to its funding problems. The provision of fresh water was another onerous financial burden associated with the housing project.

The other main, recurrent problem was land availability. Land was obviously crucial to solving the housing problem. One of the initial problems facing the Semarang council was formed by the legal issues surrounding the acquisition of land. In the case of Sompok, there was a major disagreement about the compensation to be paid to private owners for the acquisition of land needed for the construction of the drainage canal through the complex. Indeed, its construction was delayed because the owner of the land was still waiting for compensation. A similar problem arose about the acquisition of land required to construct the access road to Sompok (near the existing Jomlang-Tegalsari crossroads). Again, the landowner affected, Mrs Kastelyn, questioned the need of the expropriation and the amount of compensation offered for her land. Small landowners whose land was expropriated for the construction of housing generally had reservations about the financial compensation (Gemeente Semarang 1917). This led to protracted legal battles between the council and landowners who did not want to sell their land.

In January 1918, the Semarang council decided to establish a commission to investigate the issue of land ownership and the definition of public land. This commission established a basis for assessing land prices. By 1918 it established the principle of differential prices, with land for housing along main roads set at between 1 and 5 guilders per sq $m$ and land set back from a main road at $f 0.5$ per sq $\mathrm{m}$. Initially, the inhabitants did not want to let their land go at these prices, but eventually they were forced to accept the compensation being offered (Gemeente Semarang 1918).

Learning from such experiences, the municipal administration and the NV Volkshuisvesting later ensured they settled the price and the matter of the possession of the land before elaborating their development plans. In the case of Candi Baru and Mlaten, this involved making an initial down payment (panjer) based on accurate surveys made at the time of the transaction. 


\section{Kampong Sompok as a Gateway to Modernity}

Despite the modest nature of the houses being constructed by the municipal council, the public housing estates imposed a dramatic intervention on the lifestyle of those Javanese who were selected - or opted - to rent there. ${ }^{1}$ The areas were clearly destined not to be for 'ordinary' Javanese. As one interviewee expressed it when remembering the pre-war inhabitants of Sompok:

Complex Sompok was one of the colonial housing complexes. They were usually the preserve of the well-off families. Another example was kampong Blimbing. We could not live there, because we did not have the money to rent. Today, Complex Sompok can be compared to Perum Tlogosari [a middle class neighbourhood] (interview with Said, 77 years old, 2004).

The new estates were often the subject of newspaper articles. For instance, two contributors described the conditions in the housing complex in and around the kampong at length in the Malay language magazine Oedaja (Soedarso and Amaloedin 1928). These new, innovative projects often featured in the promotion of the 'modern' Netherlands Indies. For instance, a book on tourism, Nederlandsch-Indië, contained pictures of the modern housing in Candi Baru (see also Figure 7.2). The latter photographs remove any lingering doubts that the new buildings represented a significant departure from the urban kampong at the beginning of the twentieth century, such as those shown in the photos taken by Tillema twenty-five years earlier.

Another interviewee emphasized what he remembered about the houses:

The condition of the house was good, because the local government always ensured that the area around the housing complex was kept clean. They cleaned the small river in the housing complex periodically. The houses were small, $6 \times 4 \mathrm{~m}$, but the back and front yards were well laid out. So it was very beautiful. In the past there were small paths and parks, which were also beautiful. People often spent their time strolling in the park. The Europeans usually chose [to live] in the houses on the main road (interview with Soeparno, 61 years old, 2004).

1 At the risk of stating the obvious, I should perhaps emphasize that, of course, conversely traditional Javanese domestic practices influenced European domestic life in many ways, such as the habit of taking baths daily (Soekiman 2000). 


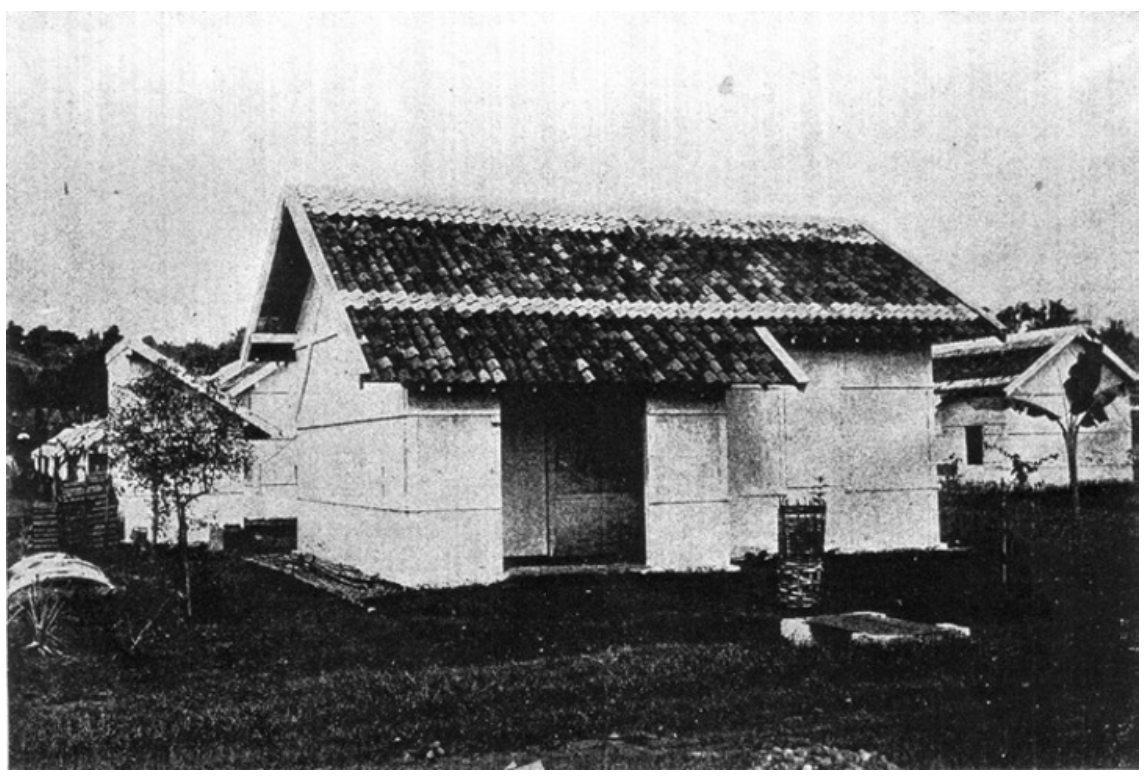

FIGURE 7.2 A healthy house in Candi

SOURCE: VERSLAG GEMEENTE SEMARANG 1918

The houses into which these better-off indigenous residents of Semarang moved were indeed quite different from those they were used to. Most came from inner city kampongs, where the houses were more or less similar to the traditional rural village houses, which had evolved as part of Central Javanese culture. After moving to the modern housing of Sompok, interviewees recalled they felt like a 'modern person'. The house was distinct from a traditional one: it had a bathroom, clean water, and electricity. Moreover, the housing estate provided a beautiful park and street lighting. Colonial health regulations required that the traditional palm leaf (atap) roofing be replaced by tiles as a plague prevention measure. Public health had been a major concern for the municipality and it therefore lay at the core in the design of houses.

Generally speaking, the facilities of the housing estate also created a new cultural environment. The new configuration of house and locale created a new perception of the house and the new environment inaugurated a broader change in society as a whole: from what might be termed a paguyuban society (Gemeinschaft) to a patembayan society (Gesellschaft); in other words it transformed from a traditional to a modern society (Budihardjo 1986:69). This change is vividly remembered by a former resident:

Yes, I still remember Sompok housing. It was a gemeente housing complex. The people who lived there were officials of the colonial 
government and the [ordinary] indigenous inhabitants were not allowed to settle there. Only civil servants could reside there. The estate was controlled and cleaned by the municipal council, we could not put rubbish anywhere; there was a privy and also sewerage. Today, the well is still there but the privy is not. The sewerage was over there. In front of Mrs Lestri's house there was a drain, [through which] the water flowed swiftly (interview with Said).

In contrast to a European house, which had several rooms, each with its own function, there were no divisions in a traditional Javanese house. The division of the house into rooms introduced the concept of privacy through spatial arrangement. Initially these internal divisions made the inhabitants feel uneasy since, in Javanese culture, a house was a micro-model of the cosmos and belief system. Over time, however, people absorbed the hybrid influences introduced by the internal arrangement of the new houses.

Another novelty to which the residents of the Kampong Gemeente had to adjust was the integral role of the bureaucracy in their housing. In order to be allocated a house in a public housing estate, people had to register with the municipal offices and municipal officials would consider their application before deciding whether to select them or not. The function of bureaucracy, as Max Weber has argued, was to guarantee the impartiality of rule and to define the relationship between task and responsibility. In terms of the Weberian Idealtype, civil servants needed to work as professional and neutral agents, immune to outside interests, and focus on the effectiveness of their work in realizing the goals set by government. In that sense, the housing bureaucracy as a whole also became a machine, which embodied the modern intentions of the municipal government.

One of the effects of the new bureaucratic procedures was increased discipline. Tenants of public housing were now required to pay their rent according to a strict time schedule. Failure to pay meant that they had to leave the municipal kampong.

When I was child...in the colonial era, before Japanese occupation...my father worked for the government, so my father was assigned a house in Kampong Gemeente (Manggis, Jeruk, Blimbing). The houses were rented, so we had to pay the bill every month (interview with Soenarto Padimin, 75 years old, 2004).

Privies formed another area in which the inhabitants of the public housing complexes were faced by new experiences that challenged traditional 
attitudes and demanded new 'modern' behaviour of them. The municipality reported in 1919 that many times the inhabitants complained about the system of closed drains running behind the houses. Privies were constructed along these drains, and at the upper end of the drain there was a facility for washing clothes and bathing in the water flowing through this drain. The drain with the privies strung along it and a bathing and washing facility at one end had been provided for each row of houses in order to improve sanitary conditions in the municipal kampong. The municipal administration intended to accustom its inhabitants to leading a more hygienic life. The inhabitants rarely used the bathroom, because they preferred to take a shower in the open. The inhabitants also preferred to put faeces in a hole in the ground and heap earth over them, rather than use the privies. In the face of obvious resistance, the municipal council hired a person whose job it was to clean the privies and gutters to ensure that kampong cleanliness was maintained (Gemeente Semarang 1919).

Later inhabitants began to appreciate the toilets. In complex Mlaten, for instance, shared facilities were built for bathing, washing, and privies (Figure 7.3). It turned out that many people were willing to pay slightly higher rents in order to have a private bathroom. This willingness was indicative of a growing individualism (Westbroek 1932:16).

Perhaps there were less drastic changes in furnishing the house. One European observer remarked in the late 1930s that, even in traditional kampong houses, typically consisting of one room (in rural areas), people were inclined to adopt Western habits. Somewhat disparagingly, he continued that, if people could afford them, the Javanese were

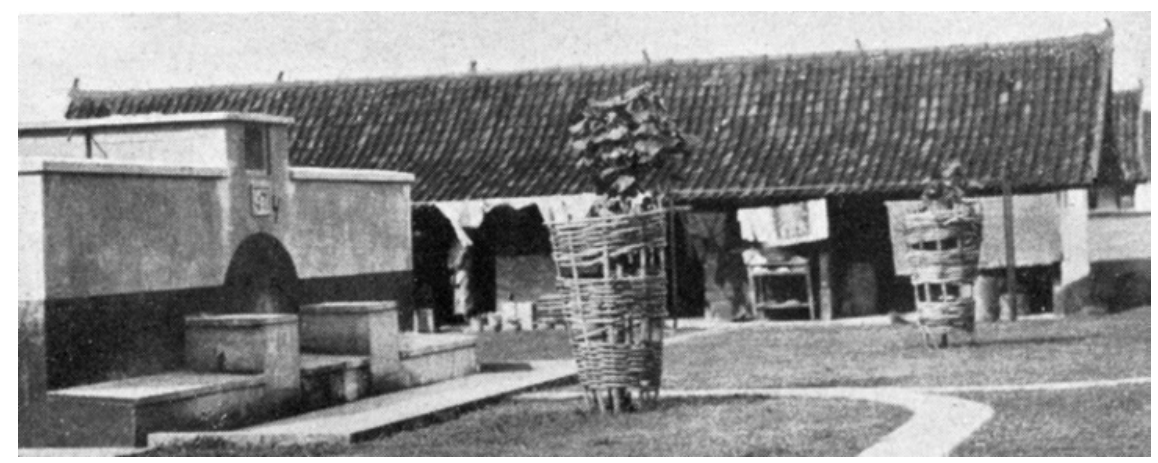

FIGURE 7.3 Shared facilities for bathing, washing and defecating, Mlaten SOURCE: WESTBROEK (1932:16) 
convert[s] to European furnishings at their very worst. Wardrobes and "whatnots," china cabinets, occasional tables, and Nottingham lace curtains are his delight. He does not feel his home complete without an immense iron double bed for the heads of the family. PONDER 1990 [1942]:84-85

\section{Class Distinctions}

The attractions of the new modern housing developments were hard to ignore and many people wanted to live there. However, not all people could afford the relatively high rents. The majority of those who could were the new class of State officials who could afford the rents. Mrs Sutopo provides the following picture of such a family, which seems to be typical of the occupants in the 1930s:

At the time our family was quite prosperous. My husband's first salary was 174 guilders per month. From this, we used $f_{15}$ for renting the house, $f_{2}$ for electricity, $f_{1.50}$ for paying the housekeeper, $f_{5}$ for the driver, $f_{5}$ for paying for a sewing machine, $f 3$ for paying for a generator (dynamo), side-dishes (laukpauk) 20 cent per day or $f 6$ per month, and 40 kati rice of 2.5 cent each. We could save 100 guilders each month. [...] We were able to resist going to any meetings, let alone parties. We even did not go to the cinema. We only played tennis, which was our favourite way of keeping healthy.

SUTOPO 1981:305

An official receiving a salary 174 guilders per month could be classified middle class. On such a salary, they could have afforded to go to the cinema, one of the characteristic pastimes of the modern family in 1930s, but this woman specifically identified her family as abstaining from both political and 'modern' activities. Indeed, while the modern surroundings and secure income made many new activities possible, this did not mean that traditional aspects of Javanese life disappeared. As the following account indicates, in the domestic environment of the middle class home, many aspects of traditional female-centred life continued:

One day at 11 a.m., I had finished my work. The three of us were sitting on the veranda $[\ldots]$. Emmy pretended she was at the market with a little basket filled with coloured leaves and various flowers she had plucked in the 
schoolyard. Because of the heat, my grandmother had discarded her kebaya, and just wrapped a cloth chest (kemben) around her. The long cloth decked her torso. She had her favourite game, dakon. I was finishing a piece of embroidery around a leg of my trousers.

SUTOPO 1981:303

Such reminiscences suggest that the lifestyle of these middle class families was a combination of traditional and Western culture. The clothing of the grandmother and 'playing market' suggest a traditional orientation. Embroidery, on the other hand, was a popular domestic activity borrowed from European women (and popularized in the new Indonesian language women's magazines of the day). Mrs Sutopo's family was from a priyayi (Javanese upper class) background. People from this new priyayi class thought they needed to demonstrate their commitment to Western culture to support and promote their prestige in the colonial society. They betrayed this way of thinking in their outward appearance, in the activities they undertook in daily life, in the discipline applied to work and so on.

Sompok also included families of a distinctly lower social class. These lived in kampong Manggis, Jeruk, and Rambutan. In Complex Mlaten social divisions could also be discerned and here lower class families lived in the kampong Krakatau, Hawa, and Hiri. The everyday classification of people, apart from being defined by the quality and style of houses they inhabited, was also based on lifestyle and what they ate. These class distinctions were recognized in the new housing complexes:

Some people employed by the municipality were lower class. Yes, they lived in those houses over there in Kampong Manggis. Today, though, the houses in Manggis have been extended. Then, a government employee used to live in Kampong Manggis; he cleaned the gutters and could buy a house in Manggis. As for the higher class, they lived in Lamper Sari. My house was in Kampong Jeruk. [...] The houses there were beautiful. Now all the houses are beautiful and they have been sold by their former owners (interview with Said).

All in all, housing design and the selection of who lived in which kampong played an important role in establishing new class distinctions in Semarang. It should be noted that not all residents were indigenous. A 1932 survey in the housing complex of Mlaten revealed that 1899 people occupied 663 houses built by the NV Volkshuisvesting Semarang. Of these people, 1180 were indigenous, 505 Chinese, 207 European, and seven were classified as other (Westbroek 1932:16). 


\section{A Micro-view of Decolonization: Sompok in the Mid-Twentieth Century}

Towards the end of the colonial period, the intensity of state intervention declined. The kampong took on a life of its own. Inhabitants were increasingly accustomed to the experience of employment in modern offices and the consumption of modern media. Despite rising nationalist politics to which urban intellectuals were attracted, in many ways the lives of new urban kampong dwellers came closer to that of the Dutch. Although a social and cultural distance remained, expressed for instance in terms of address, the urban population as a whole became more integrated by the use of terms such as tuan, nyonya, sinyo whereas in the village, older terms of respect, such as nDoro, Den, jeng tended to survive.

Typical of many reminiscences of an older pre-war generation is the following:

Yes, we lived here, got married here, and have stayed to the present. Well, people said that the Dutch were colonial, but they were kind. We did not have any complaints. Yes, we are good persons and we have stayed here for years. We never fight and we have always got on well with the neighbours, because all of other the people are good, too (interview with Bisirkulin, 77 years old, 2004).

Good relations between indigenous people and the colonial overlord can also be seen in mixed marriages. For instance, in 1940 a person from an old kampong married a member of the Koninklijk Nederlands-Indisch Leger (KNIL, Royal Netherlands Indies Army) living in a nearby boarding house; the relationship continued after Independence:

When I was a child, my life was wonderful because my sister married a soldier of the KNIL. At that time their position was good. Sometimes people even called me a friend of the Dutch. [...] Sometimes we were helped by those KNIL people. They were like us, indigenous inhabitants. They often gave us food, like bread. In the 1950s I liked to hang around with sinyo-sinyo [European or Eurasian youths]; when they were playing, I just watched (interview with Margono, 70 years old, 2004).

Relations between people in the housing complex and the surrounding older, unplanned kampongs intertwined. For instance, people living in Sompok employed personnel from the older kampong to do domestic chores. As one of the former domestic aides recalls: 
We had good relations there. They [middle class people in Sompok] had a housekeeper who was one of us and sometimes we also asked to go with them. At that time, there was the Dutch Meneer Mengrut. He lived with his housekeeper and she gave birth to a baby. Nowadays the child is living in Holland. Mr Mengrut has died (interview with Soeparno, 70 years old, 2004).

\section{Kampongs during the Japanese Occupation and Beyond}

The arrival of Japanese soldiers brought significant changes to the inter-class and inter-ethnic relationships, which had developed over the past two decades in Sompok and Mlaten. During the first days of the occupation, the Europeans fled from their houses. Many indigenous people from the surrounding kampong took advantage of this to steal goods from the empty houses in Sompok.

Indigenous attitudes towards the Japanese were mixed. Semarang-born novelist Nh. Dini recalls how one day five Japanese soldiers suddenly appeared standing in the field that separated their house from a river. The kampong people gathered to watch them and so did, from behind their fence (pagar), Dini and her family. The soldiers were speaking angrily. Two of them broke down the fence without warning and came into their backyard. They took the iron clothesline. The second time they came and took the clothesline, Dini watched them from nearby. 'These people were the army which my father called the liberator from the [Dutch] colonizer!' (Dini 1979:9).

The social differences grew smaller, at least on the surface. The Japanese treated the Javanese as equals, especially if they were willing to co-operate with the new overlords. Dini was keenly aware of the changing social relations, and not only because her father, who continued to work for the railways, earned less and less.

The social system kept in pace with the propaganda [proclaiming] that all people were of the same status, with the slogans "Japan-Indonesia together," "Co-Prosperity in Great East Asia" and the like. It took my mother a long time to get used to being called "Bu," a title addressed to her by the neighbours in the kampong who had once addressed her with [the more respectful title of] "Den" of " $n D o r o . "$

DINI 1979:10-11

Conditions changed dramatically when the Japanese military government designated the modern housing complexes of Sompok (Lamper Sari) and Mlaten 
(Halmahera) as an internment camp for Europeans. These complexes, once the sites of modern humanity, became places of inhumanity. The kampongs were sealed off from neighbouring housing by a high bamboo fence. The houses, designed for modern Indonesian families, were now all occupied by Dutchmen. Women and men were separated. Lamper Sari (Sompok) was designated for women and children, and Halmahera (Mlaten) was occupied by men. These kampongs were eventually to house a large majority of all European civilians in Central Java. By January 1944, Lamper Sari was the biggest women's and children's internment camp in Indonesia, with up to 8,00o internees (Fenton Huie 1992:69). The small, two-room houses in Lamper Sari were occupied by twenty to twenty-five internees each. Sanitary conditions in the modern houses collapsed completely; government officers no longer supervised the cleaning of the complex. The hygiene deteriorated alarmingly and this breakdown caused the death of many internees.

As the Europeans were gradually concentrated in two parts of Sompok and Mlaten and thus removed from other parts of Sompok and Mlaten, indigenous people had the opportunity to enjoy the modernity more directly. They could go into the modern houses without feelings of humility or inferiority. Meanwhile, the European internees, increasingly suffering from a lack of food, exchanged their possessions for fresh food (eggs, chicken, fish, meat, rice and so forth) brought by inhabitants of neighbouring kampongs. Through this exchange, items of modernity were disseminated among the indigenous people, such as clothes (jackets, shirts, shoes), cameras, jazz records and the like. At least at the beginning of the Japanese rule, the boundary between the internment camp and the neighbouring kampong assumed the appearance of a market.

The Japanese period thus had two contradictory effects on the modernization of kampong life. With the disruption of the municipal apparatus, modern ideals of cleanliness, hygiene, and order had to be dropped, especially in the parts that functioned as internment camp. Simultaneously, however, the consumption of modernity spread to a new group of indigenous people who purchased at bargain prices modern consumer items hitherto unaffordable to them. This paradoxical situation ended when the Japanese army surrendered.

Social changes continued after Independence. Many of the new residents of kampong Nangka and Mangga were civil servants. After 1958, the proportion of indigenous residents increased when the Dutch were forced to leave Indonesia as a result of political conflicts between Jakarta and The Hague. Especially Kampong Lamper Sari had many newcomers because the military took over the houses from the Dutch. Although distinctions remained, the Sompok area and its residents came to be increasingly integrated into the surrounding 
kampongs through a cultural dialogue that, in time, created a common community characterized by individualism, efficiency, and functionality.

\section{Conclusion}

Housing plays an important role in developing a city and constitutes the largest area of the modern city. Arguably, it is in terms of housing that the modernizing influence of colonialism in the Indonesia city was most prevalent. In Semarang, as in other colonial cities, the colonial municipality was an important modernizing agent. It intervened directly in the process of housing by town planning and by the development of public housing complexes such as those of Sompok and Mlaten. In the process, the face of the city changed.

The public housing projects gave rise to the formation of new urban spaces, new communities, and new habits. Modern housing had an effect on sanitary behaviour (for instance, the use of showers and toilets), the discipline to follow the calendar in order to pay the rent on time, interaction with neighbours, and self-esteem. However, the continued interaction of the residents of the new housing projects with older urban and rural communities ensured that a dynamic process of multifaceted cultural interaction continued to produce, over time, a specifically modern Indonesian urban identity. People adopted some of the changes without ever giving up all traditional values and practices. As a consequence, modernity in the twentieth century Indonesian urban kampong developed as a homegrown, hybrid way of life.

In this hybrid form, modernization was a powerful force. Since modernization, both as a conceptual notion and as a physically embedded part in the urban landscape, was such a powerful element in the late colonial period, housing experienced very little change in its built form at the end of colonialism.

After decolonization, modernization might have changed pace, but not direction.

\section{References}

Budihardjo, Eko (1986). Arsitektur dan kota di Indonesia. Bandung: Alumni.

Colombijn, Freek (with the assistance of Martine Barwegen) (2010). Under construction: The politics of urban space and housing during the decolonization of Indonesia, 1930-1960. Leiden: KITLV Press. [Verhandelingen KITLV 246.]

Colombijn, Freek (2011). Public housing in postcolonial Indonesia: The revolution of rising expectations, Bijdragen tot de Taal-, Land-en Volkenkunde 167:437-458. 
Coté, Joost (2002). 'Towards an architecture of association: H.F. Tillema, Semarang and the discourse on the colonial "slum", in: Peter J.M. Nas (ed.), The Indonesian town revisited, pp. 319-347. Münster: LIT and Singapore: Institute of Southeast Asian Studies.

Dini, Nh. (1979). Padang ilalang di belakang rumah: Cerita kenangan. Jakarta: Dunia Pustaka Jaya.

Dumarçay, Jacques (1987). The house in South-East Asia. Singapore: Oxford University Press. [Translated and edited by Michael Smithies.]

Fenton Huie, Shirley (1992). The forgotten ones: Women and children under Nippon. Pymble: Angus \& Robertson.

Flieringa, Gellius (1930). De zorg voor de volkshuisvesting in de stadsgemeenten in Nederlandsch Oost Indië in het bijzonder in Semarang. Rotterdam: Rotterdamsche Boek-en Kunstdrukkerij Rotterdam. [PhD thesis, Technische Hoogeschool Delft.]

Gedenkboek (1931). Gedenkboek der gemeente Semarang 19o6-1931. Semarang: De Locomotief.

Gemeente Semarang (1917-1919). Verslag van den toestand der gemeente Semarang over [...]. Semarang: Gemeente Semarang.

Liem, Thian Joe (1931). Riwajat Semarang 1416-1931: Dari djamannja Sam Poo sampe terhapoesnja Kongkoan. Semarang: Ho Kim Joe.

Nas, Peter J.M. (1998). 'The house in Indonesia: Between globalization and localization', Bijdragen tot de Taal-, Land- en Volkenkunde 154:335-360.

Nas, Peter J.M. and Welmoet Boender (2002). 'The Indonesian city in urban theory', in: Peter J.M. Nas (ed.) The Indonesian town revisited, pp. $3^{-17}$. Münster: Lit and Singapore: Institute of Southeast Asian Studies.

Ponder, H.W.(1990 [1942]).Javanese panorama: More impressions of the 193os. Singapore: Oxford University Press. [Originally published as Javanese panorama, London: Seeley Service, 1942.]

Rückert, J.J.G.E. (1930). 'Volkshuisvesting II', in: W.F.M. Kerchman (ed.), 25Jaren decentralisatie in Nederlandsch-Indië 1905-1930, pp. 162-173. Semarang: Vereeniging voor Lokale Belangen.

Semarang (1919). 'Semarang', in: D.G. Stibbe (ed.), Encyclopaedie van NederlandschIndië Deel III, pp. 742-744. 's-Gravenhage: Martinus Nijhoff and Leiden: E.J. Brill. [Tweede druk.]

Shiraishi, Takashi (1997). Zaman bergerak: Radikalisme rakyat diJawa 1912-1926. Jakarta: Pustaka Utama Grafiti.

Soedarso, and Amaloedin (1928). 'Volkshuisvesting te Semarang', Oedaya 10:10-12.

Soekiman, Djoko (200o). Kebudayaan Indis dan gaya hidup masyarakat pendukungnya diJawa (abad XVIII-medio abadXX). Yogyakarta: Yayasan Bentang Budaya, Yayasan Adikarya Ikapi and Ford Foundation.

Stevens, Theo (1986). 'Semarang, Central Java and the world market 1870-1970', in: Peter J.M. Nas (ed.), The Indonesian city: Studies in urban development and planning, pp. 56-70. Dordrecht and Cinnaminson: Foris. [Verhandelingen KITLV 117.] 
Sumalyo, Yulianto (1993). Arsitektur kolonial Belanda di Indonesia. Yogyakarta: Universitas Gadjah Mada Press.

Suryo, Djoko (1982). Social and economic life in rural Semarang under colonial rule in the late 19th century. Clayton: Monash University [ $\mathrm{PhD}$ thesis, Monash University, Clayton.]

Sutopo (1981). 'Ny. Sutopo', in: Lasmidjah Hardi (ed.), Sumbangsihku bagi pertiwi (Kumpulan pengalaman dan pemikiran), Buku I, pp. 291-311. Jakarta:Yayasan Wanita Pejoang.

Tillema, H.F. (1913). Van wonen en bewonen, van bouwen, huis en erf. Tjandi-Semarang: [Tillema].

Tillema, H.F. (1922). "Kromoblanda": Over 'tvraagstukvan "het Wonen" in Kromo's groote land. Vol. 5. [s.l.: s.n.].

Verslag gemeente Semarang (1918). Verslag gemeente Semarang 1918. Semarang: Gemeente Semarang.

Volkstelling 1930 (1936). Volkstelling 1930/Census of 1930 in the Netherlands Indies, Volume VIII Overzicht voor Nederlandsch-Indië. Batavia: Departement van Economische Zaken.

Westbroek, H. (1932). 'Exploitatie en bebouwing van het land Mlaten Semarang', Locale Techniek 1(1/2):10-21.

Westerveld, D.J.A. (1910). Verslag van een onderzoek naar de levens-en woningtoestanden in Noord-Oost Semarang gehouden door het bestuur der Semarangsche Kiesvereeniging. Semarang: Van Dorp. 